\title{
Mapping the fit: library and information services and the national transformation agenda in South Africa, Part I I
}

\author{
Christine Stilwell ${ }^{\prime}$ \\ Information Studies, University of KwaZulu-Natal \\ stilwell@ukzn.ac.za
}

Received: 10 August 2008

Accepted: 14 May 2009

\begin{abstract}
An update of an article which appeared in the IFLA journal (Stilwell, 2007a), this article follows on from Part I (Stilwell, 2008) charting progress in terms of the fit between available library and information services and that which is expected in terms of the national transformation agenda. This second article picks up on libraries and information services in South Africa as part of the wider national information system, starting with school libraries. An overview of archives, record centres and museums, non-governmental organisations (NGOs), embassies, commercial database industry and indigenous knowledge follow. The sectors concerned with the dissemination of information and information technology are described as well as the library and information education and training sector and the organised profession. This overview is based on literature retrieved from the available, mostly electronic, databases.
\end{abstract}

Keywords: Library and information systems and services; access to information; education and training; South Africa

\section{Introduction}

In this article we pick up on the critical questions of the school library sector before reviewing other information services. As with Part I of this two part article, Boon's four broad categories (1992) for the information sector are used for structuring much of the contents. School Libraries are located within libraries and information services in the sector concerned with packaging, storage, organisation, recall and duplication of information. Some of these services were reviewed in Part I.

\section{Information sources, systems and services in South Africa}

Within this section we continue to map the sectors responsible for the packaging, storage, organisation, recall, duplication and dissemination of information. In addition the sector concerned with information technology is discussed.

\section{I Sector concerned with packaging, storage, organisation, recall and duplication of information}

We go on with charting the progress of libraries and information services in South Africa, reviewing this against the imperatives of the government's transformation agenda, commencing with the critical problems of the school library sector.

\section{2 Libraries and information services}

\subsection{School libraries}

For school libraries the development of standards and policy falls under the Department of Education. The actual provision of school library facilities is a competence shared by the National Education Department, the provincial authorities and the school governing body. De Vries and van der Merwe (2004) explain how the National Norms and Standards for the Funding of Schools (Department of Education, 1998) were to be implemented in the provinces in 1999. The adoption of this framework in the Northern Cape led to an improvement in funding for schools in this province.

In 1999 a national survey of school libraries was undertaken to inform improvements in "the capacity of the Department of Education to systematically take stock of its school library resources in terms of their quality, quantity and spatial distribution" (Department of Education and Human Sciences Research Council, 1999:iii). In 2006 the total void in terms of legislated school library policy at national level appeared to be receiving attention at last. A national policy for school library norms and standards supported by the Minister of Education, Naledi Pandor, was expected to be passed late that year. Pandor also resurrected the 1997 National policy framework for school library standards and made an explicit connection publicly between the development of school libraries and literacy levels (Department of Education, 2005; Zinn, 2006:23). Zinn (2006:23), however, states "the policy and its implementation still have a long road to travel". Jenny

I. Christine Stilwell is Professor, Information Studies Programme, University of KwaZulu-Natal, in Pietermaritzburg, South Africa. E-mail stilwell@ukzn.ac.za. 
Roualt-Smith, Deputy Director General Curriculum of the Department of Education of South Africa cited by Gxwati (2007:I) reported somewhat equivocally at the IFLA conference in 2007 that the Minister "wanted statistics before approving the school library policy".

Changes in the funding formulae for library materials for schools mean that such library funds are no longer ringfenced (Zinn, 2006:33). Boekhorst and Britz (2004) reported on the state of information literacy at school level in South Africa in relation to the role that libraries could play in this regard and found that the role of the library was undervalued. Zinn (2006:33) notes that there is a much more energetic campaign around reading per se rather than around libraries as enablers of reading. Gxwati (2007:I) reports a statement by Roualt-Smith that the lack of access to reading resources was the chief cause of poor reading skills and that the majority of South African learners had "very, very, poor reading skills". Poorly integrated ICT programmes and a tendency to prefer driving ICT programmes to focussing on libraries and books further impedes the development of holistic library-based information literacy programmes (Zinn, 2006:33).

In an article entitled "Getting children reading" in The Witness on 4 June 2008, Clare Verbeek from the University of KwaZulu-Natal's Faculty of Education states that:

... reading aloud to children should be a daily part of literacy instruction. In spite of the policies, my research shows that in many classrooms this is a rare occurrence. Reading aloud to children models good reading, it helps them to associate reading with pleasure, it builds vocabulary and world knowledge, and it offers a chance to talk about the meaning of what has been read. This is particularly important for those children who do not have the privilege of book-rich homes, and I think it should be a non-negotiable responsibility of at least all primary school teachers.

As she argues, "children need daily opportunities to read both in and out of their classrooms" as "reading improves with regular practice". She supports the provision of a range of reading materials in classrooms. Zinn's recent survey results (2006:30) mirror the findings of a 1999 survey which found that fewer than 30 percent of South African schools had the central or classroom libraries needed to support the reading activities (Department of Education and Human Sciences Research Council, 1999) Verbeek describes.

Rural areas were even worse off in the mid 1990s than their urban counterparts, with the School Register of Needs Survey (Department of Education, 1997:8) reporting that primary school libraries in the highly rural provinces were virtually non-existent. Some provinces reported as few as 2 percent of schools having libraries. As there was a national shortage of 57,499 classrooms (Department of Education, 1997:9), building classrooms was prioritised above the building of libraries (Le Roux and Hendrikz, 2006:623). By 2002 a vast proportion of schools, 78 percent, were still without a school library (Zinn, 2006:23).

A recent study by Du Toit (2008) throws light on the current situation in KwaZulu-Natal. She combined data from two surveys, the 1999 national survey (Department of Education and Human Sciences Research Council, 1999) which also provided data on KwaZulu-Natal and a 2004 Education Library and Information Technology Services (ELITS) School Library Audit (KwaZulu-Natal. Department of Education, 2004) to map school library provisioning and administration in the province. She was able to identify the extent to which services had improved or deteriorated between 1999 and 2004.

There were differences in the data collection methods of the two surveys, but she was able to conclude in relation to the 5156 schools surveyed by ELITS and the 4773 schools surveyed by the Human Sciences Research Council that more schools had access to some type of library provisioning in 2004 than in 1999: 3516 of the 4773 schools (73.6 percent) indicated that they had no library in 1999 and only I 003 of the 5 I 56 schools ( 19.5 percent) had no library provisioning in 2004. There were 2187 schools (42.4 percent) with either a classroom or central library in 2004 compared to I 148 schools (24 percent) in 1999. Despite suspected over-reporting by school staff (Du Toit, 2008), there is clearly some improvement in this province. Many challenges to further improvement remain.

Du Toit (2008) wanted to highlight the landscape in which schools sought to provide and maintain school library services. This point is one taken up by Ocholla (2006) who states that the majority of school children in deep rural areas have no access to libraries of any kind despite the government's attempts to provide service through multi-purpose community centres. Nzimande and Stilwell (2008) explore some of the impediments to such projects, such as a lack of adequate community awareness raising and participation at the planning stage.

Zinn (2006:22) argues that the central problems emerging in this sector are those of quality and socio-economic class. South Africa has adopted a system of outcomes-based education, refined in Curriculum 2005, where the role of the school library as a provider of learning resources should be of paramount importance. However, there is little evidence for any high regard for libraries existing within the system. De Vries and Van der Merwe (2004:128) add that "the gap between affluent schools and the disadvantaged schools" has not really been reduced, "poor people have to contribute a disproportionate share of their income to the education of their children". This is a matter of considerable concern

SA Jnl Libs \& Info Sci 2009, 75(I) 
because in these schools "class has replaced race as a condition of entry" (Zinn, 2006:22). Implementation of the outcomes-based curriculum has been most successful in middle-class schools, the formerly white schools where parents pay fees to employ additional teachers and improved resources to support a higher standard of teaching (Chisholm, 2005:2 I I). In 2007 measures are in place to alleviate the plight of poor families in terms of fees (Waka-Zamisa and Shoba, 2007), but the funding of school libraries remains uncertain.

Karlsson (2005), a librarian and educationist, coins the phrase the "blind spot of the education authorities". Despite tests revealing low reading levels among Grade 3 learners, the Western Cape Education Department (WCED) devised solutions that ignored the role of the school library (Zinn, 2006:23). At national level, as noted above, until very recently there has been a total void regarding champions for the library and information sector's role in education. In the absence of school libraries, the provision of support for schools passes to public libraries, who feel unprepared for such a role (Hart, 2006a:2006b).

Zinn (2006:23) praises the evidence-based research of a 2005 study, a systemic evaluation of Grade 6 learners, which identified access to information as key to learner achievement and recommended that school libraries, trained school library staff, well-stocked libraries and pre-service educator training in school library management be prioritised (Western Cape Education Department, 2005:101-102,108). This study is one of two research studies by the Western Cape Education Department (2005 and 2006) stressing the importance of school libraries. The second study (Western Cape Education Department, 2006) focussed on ICT literacy as well as school library provision.

On a positive note, too, Zinn reports that schools have begun to establish new school libraries and to re-establish old ones. Minister Pandor has resurrected the 1997 national policy framework (Department of Education, 2005; Zinn, 2006:22-23), but in 2008 there is still no national policy for school libraries. A positive sign was Minister Pandor's participation in 2007 in a Rally to Read convoy to North West province to a selection of rural schools (Department of Education, 2007). The Rally, a co-operative venture of the Financial Mail, McCarthy Motors and Read Educational Trust, targeted seven provinces where portable classroom libraries, science kits as well as teacher training would be delivered to schools over a three year period.

The White Paper on e-Education (Department of Education, 2004) revealed that many local schools lacked basic ICT infrastructure. Zinn reports a growing awareness of computers and found that 95 percent of her respondents' schools had access to computers, with 72 percent having Internet access. All high schools had at least one computer laboratory, but most still did not use computers to generate knowledge or to integrate ICT across the curriculum. Computers in schools are mainly used for administrative purposes (Wilson-Strydom, Thomson and Hodgkinson-Williams, 2005:79).

Le Roux and Hendrikz $(2006: 618,630,634)$ argue for the use of partnerships in supporting access to computing for schools and describe a project in the Maphotla community in Mpumalanga involving various stakeholders The project aimed to address provision to remote rural areas through the use of joint school/community libraries which would form the central node for a cluster of schools. Variations on the cluster model have been explored for use in the remote rural areas of KwaZulu-Natal in an attempt to find a way forward for this sector (Nzimande and Stilwell 2008).

School libraries generally lack suitably qualified and motivated staff. The South African School Library Survey 1999 (Department of Education and Human Sciences Research Council, 1999) found that in all provinces except Gauteng, fewer than 20 percent of the staff responsible for the school library were appropriately qualified. Over the last 10 years teacher librarians have been retrenched or assigned to other duties (Le Roux and Hendrikz, 2006:620). Le Roux and Hendrikz (2006:62I) and Hart (2006a; 2006b) return to the issue of public librarians being expected to play a role in serving school learners and in developing lifelong information literacy.

How can this lack of qualified staff be addressed? A collaborative schools-based project was the Library Practice for Young Learners (LPYL) initiative which ran from 1997 to 2002 and involved Swedish and local structures. It emerged out of the historical anti-apartheid links of the Library and Information Workers Organisation (LIWO) and Bibliotek I Samhalle (BIS). LPYL was a broad based project aimed at inspiring and supporting local educators (Library Practice for Young Learners, 2002).

Hoskins (2006:59) describes a development in which access to education and training is supported by bursaries for an Advanced Certificate in Education (ACE) for School Library Development and Management students at the University of KwaZulu-Natal (UKZN) in partnership with the KwaZulu-Natal Education Library and Information Technology Services (ELITS). The funding stems from a partnership between ELITS and the Royal Netherlands Embassy which requires that the programme be delivered at remote rural resource centres in KwaZulu-Natal. The Departments of Library Science and Distance Learning at the University of Fort Hare (Libraries for South African schools, 2008) support a similar project the Eastern Cape.

Another KwaZulu-Natal initiative is described by Rosario and Molapo (2005) in the form of the Shongololo Interconnectivity Pilot Project, which provides technological links between 20 schools in the province and 20 schools in 
the United Kingdom. The main aim of the project was to enable learners to communicate with each other via e-mail to "mutually solve problems, identify and enjoy differences, and discover commonalities". Other plans were related to information retrieval from the Internet, teacher exchanges and fundraising for local schools. The project faced some major challenges, but is now well placed to inform other connectivity initiatives.

Archives, record centres and museums

The role of the archive in the new democracy has been the subject of extensive debate. Merrett (2005:18) states that "archives are a key component in the complicated structure that is the national information system". The Truth and Reconciliation Commission's work of confronting the past revealed how many records have been lost (Harris, 2002).

The preservation of archival materials in South Africa is regulated by Schedule 5 of the Constitution of the Republic of South Africa (1996) and the National Archives Act (1996). The Act defines the separation of functions between the national government and the nine provincial governments. It also provides for a National Archives Advisory Council. The National Archives and Records Service of South Africa (NARSA) and the provincial archives services fall under the Department of Arts and Culture. All the provinces have a provincial archives service. These are located in King William's Town, Bloemfontein, Ulundi, Giyani, Nelspruit, Kimberley, Mmabatho and Cape Town. There are repositories in Pretoria, Port Elizabeth, Umtata, Pietermaritzburg and Durban. The National Film, Video and Sound Archive in Pretoria is a legal deposit collection, as indicated above (Ngulube, 2003:15-17,410-4I2).

South Africa has 90 archival repositories (Leach, 2007) and enjoys a wide variety of archives covering various topics such as contemporary history, Africana, newspaper archives, popular memory, religious materials, languages and eminent political figures and structures (Mostert, 2005:56). Various institutions such as the universities have their own archives and special collections.

South Africa has some 300 museums which are situated in most cities and small towns. The role of this sector, too, has been hotly debated, with many museums seeking to broaden their appeal to the wider South African public. Among the best known of the national museums are the Robben Island Museum, which features the cell in which former President Mandela was imprisoned, the Apartheid Museum in Johannesburg, which offers audio-visual footage of political events during the 1970s an 80s in apartheid South Africa, and the Transvaal Museum which houses the skull of Mrs Ples, the 2,5 million year old hominid fossil (South African yearbook, 2006/7:121-122). In addition to the national museums there are provincial museums which focus mainly on preserving and giving access to local history (Mostert, 2005:57).

\subsubsection{Non-governmental organisations (NGOs)}

South Africa has a rich history of alternative provision by non-governmental organisations The NGO community resource centres emerged in the 1980s to support the Mass Democratic Movement. NGOs still play an active role in information provision; they cover a wide variety of subject areas. In 1990 South Africa had some 120 NGO-linked resource centres, but by 1999 only about half of these had survived (Stilwell, 2001:209). After 1994 international funding was largely diverted to government, thus representing a further substantial loss for the library and information sector.

Through the Resource Centre forums, resource centres have had an influence on the transformation of library and information services for the new democracy (Stilwell, 200I), as indicated above. Some significant centres have survived, for example the Workers' Library and Museum in Newtown, Johannesburg which has "a reading library for workers and disadvantaged readers going back 80 years". This centre has been incorporated into Khanyi College and Resource Centre (Kaiser, 2006). Others are highly specialised and could be classed as special libraries. An emerging NGO that is playing a significant role in addressing social exclusion in the rural areas is the Family Literacy Project (Aitchison, 2006).

\subsubsection{Embassies}

Since its emergence as a democratic state South Africa has hosted an increasing number of foreign embassies which provide information about their own countries. Some of these also have libraries and have played a role in capacity building in the LIS sector, for instance the British Council and United States Information Service.

\subsubsection{Commercial database industry}

South Africans have access to both international and locally produced databases. SABINET Online (2007) is a major local service which provides access to I 000 different bibliographic and full-text databases. The National Inquiry Services Centre South Africa (NISC SA: n.d.) produces databases of local and African resources such as South African Studies (n.d.) and provides access to NISC's international databases (Mostert, 2005:57). Services such as Ebsco Information Services (2007), Emerald Insight (n.d.) and ProQuest (2007) provide access to full text databases.

SA Jnl Libs \& Info Sci 2009, 75(I) 


\subsubsection{Indigenous knowledge}

South Africa has a rich store of indigenous knowledge, much of which eludes capture and documentation. In recognition of the potential value of indigenous knowledge, the NRF has established a focus area for indigenous knowledge systems (Kaniki and Mphahlele, 2002:12). Kaniki and Mphahlele (2002:2,12) discuss this knowledge store in relation to knowledge management, noting that indigenous knowledge can have "value not only for the culture from which it evolves, but also for scientists and planners outside that culture". Their article gives a sense of the range of subjects involved.

The Campbell Collections of the University of KwaZulu-Natal have embarked on a digitising project to preserve and make accessible rare and fragile collections which embody the indigenous knowledge of the region, going back many decades. This project which is linked to the Digital Imaging Project of South Africa initiative relates to indigenous art, ethnographic objects and historic photographs. Peters (200I), cited by Kaniki and Mphahlele (2002:13), describes the Digital Imaging Project of South Africa and also raises concerns about opening such cultural heritage materials to commercial exploitation. This debate is likely to be ongoing. Ocholla and Bothma (2007) point to the "huge opportunity" this area offers to LIS schools to extend their curricula.

\section{Sector concerned with the dissemination of information}

\section{I Mass media}

South Africa has a well developed mass media network and relative press freedom (Merrett, 2005:18). Apart from newspapers and magazines, South Africa has the usual array of broadcasting services, radio and television.

South Africa ranks 44th out of 168 countries in Reporters Without Borders ${ }^{2}$ (RSF's) latest index of press freedom. This ranking is down from 3 Ist position in the 2005 index, but is still well within the top 50 countries said to have what is described as genuine press freedom (SouthAfrica.info, 2008b). However concern was expressed by Dick (2006) at the launch of the journal Innovation in its new format, when he asked librarians to "join other civil society organisations to condemn growing censorship across the country, the region and the continent". He lauded the emergence of the African Progressive Librarian and Information Activist's Group (PALIAct) which is linked to similar groupings in Sweden and the United States.

\subsection{Broadcasting}

The South African Broadcasting Corporation (SABC) is the major broadcasting corporation in the country and controls radio and television services on national and local levels. Twenty-four hour national services in English and Afrikaans are backed by a multitude of regional services. An external service offers coverage in English, Portuguese and various African languages (Europa World Yearbook, 2001:3597; Mostert, 2005:58). South Africa has some 36I radio broadcast stations (IndexMundi, 2007) which in 200 I serviced some 17 million radios (Communications in South Africa, 2008). Government interference in the state broadcaster (SAfm) in 2003 put it into rapid decline. In 2006 it attracted to its broadcasts only $0.6 \%$ of the total population (South African Broadcasting Corporation, 2006).

Television services are provided by the SABC, by a private subscription service, and by digital satellite broadcasting offerings from Multichoice Africa. A free-to-air service, etv, is also available (Burger, 2002; Mostert, 2005:58). In 2000 South Africa had 6 million television sets (Communications in South Africa, 2008). In May 2006 the SABC was accused of self-censorship when it decided not to air, and asked producers not to talk about, a documentary on President Thabo Mbeki. Media groups such as the International Freedom of Expression eXchange and the International Federation of Journalists denounced the trend towards self-censorship in the SABC. SAfm's AM Live anchor, John Perlman, further disclosed that the SABC had blacklisted selected commentators and analysts, with instructions issued that certain analysts could not be used on particular topics (South African Broadcasting Corporation, 2006; News24, 2006 ).

\subsection{Newspapers and magazines and newspaper archives}

A variety of national, regional and local newspapers is found as well as free "knock and drops" (Behrens, 2000). There are 17 dailies, 7 Sunday papers and 21 weeklies, in addition to the weekly community newspapers which report on local news. The languages of publication are English, Afrikaans and Zulu (Burger, 2002). At least 47 of these are online newspapers (South African newspapers 2008).

It is estimated that more than I 000 magazine titles are published in South Africa (Scholtemeyer, 2002). Consumer magazines in South Africa are sold largely via the retail sector ( 95 percent). There are two large magazine distribution companies, and two smaller ones. The subscription method of selling is not viable in South Africa due to postal

2. RSF's fifth annual Worldwide Press Freedom Index - covering the period from I September 2005 to I September 2006 - reflects the degree of freedom enjoyed by journalists and news organisations in each country, and "the efforts made by each state to respect and ensure respect for this freedom" (SouthAfrica.info 2008b). 
inefficiencies and the high cost of the postal system. Subscriptions and access via shops are on offer for approximately 300 local consumer magazines. There are over 500 trade, professional and technical publications (Burger, 2002). The number of magazine titles has grown substantially since 1994. There are now 356 magazines that have an official Audit Bureau of Circulations $(A B C)$.

Larger publications have online websites and most major newspapers, both local and international, are available online. The Mail and Guardian Online (2007) provides archived material back to 1994. There are two popular local newspaper portals, Independent Online (2007) and News24 (2007). The total advertising market amounts to US\$2.3bn, of which magazines attract II percent (Scholtemeyer, 2002).

\subsection{Internet and online-government information}

The government has launched a bimonthly magazine, Vuk'uzenzele, to offer information on opportunities and services to South Africans. It targets South Africans with limited access to the mainstream media and is published in all the official languages as well as being in Braille and online. Distributed free it is intended to reach the remotest areas in all nine provinces (Government mag to reach rural areas, 2005).

Mostert (2005:59) has listed the local sites that provide government and legal information; a few examples only are given here. The Government Communication and Information System (2007) is the major government site and is described above. It is accessible online and provides an entry point to various publications, including the South African Yearbook (2005/2006) and annual reports (Mostert, 2005:59). It also allows access to important directories such as the Contact Directory (2006) and South African Government Directory (2007) which give contact details for officials as well as bodies, structures and task groups at national and provincial level. The website, South African Government Online (2007) provides information about departments, provinces and other bodies and is linked to the GCIS site.

Information is provided by the websites of all but three government departments. Mostert (2005:60-6I) evaluates these sites, listing details of the information they offer on publications, access to speeches, reports and so on. An in-depth study of the South African Police Services (n.d.) website is reported on by Sonderling and Bothma (2005), who note that it was revamped after a GCIS audit of government websites in 200I. In particular, these authors seek to establish the website's level of success in achieving user-friendliness in an effort at "democratic outreach" in this crucial department. The Department of Labour's website (http://www.labour.gov.za/) is widely regarded as leading in terms of ease of use and the capacity for interactivity required for e-governance.

\section{Sector concerned with information technology}

Statistics on Internet connectivity worldwide suggest the extent to which the ICT access envisaged in the IFLA Internet Manifesto (above) is able to be realised. Research ICT Africa (2008) reports that only I5 percent of the South African population use the Internet, which is only just among the highest of sub-Saharan countries surveyed and is below figures for other lower income countries such as Turkey, Poland, Argentina and some Maghreb countries. For most South Africans, connectivity is achieved through work and school.

Internetworldstats.com (2007a) gives Internet usage figures (in percentages) to show the rate of penetration in relation to the population by region as follows. Africa has the lowest rate of penetration, 3.6 compared to a world rate of 16.9. This site shows, however, that Africa has the highest use growth rate for 2000 to 2007 of 638.4 percent, followed by the Middle East at 491.4 percent.

Access to telecommunications in South Africa is uneven. In 2007 South Africa had some 5, 100,000 Internet users with a population penetration of 10.3 percent which placed this country sixth on the continent (Internetworldstats.com, 2007b). South Africa's use growth rate from 2000 to 2007 of II 2.5 percent is low compared with other African countries.

In order to promote e-government, the Department of Communication in South Africa has installed public Internet terminals (PITs) in Post Offices using smart card technology to gain access (Burger, 2002; SouthAfrica.info, 2004). During the first phase of the project, specially trained community development workers were to be deployed at nine selected MPCCs and at 55 postal facilities. Services in high demand such as pension payouts and birth and death registrations would be e-enabled first (SouthAfrica.info, 2004). The first intake of I 300 community development workers completed a one-year training programme at institutions such as the University of the Western Cape in 2005 and in November of that year 900 were recruited (SouthAfrica.info, 2005).

The importance of equity in access was clearly high on the agenda of Public Service and Administration Minister Geraldine Fraser-Moleketi, who argued that public service delivery to all citizens could be improved by the use of technology and that slow forms of development in this regard needed to be leapfrogged (Emdon, 2002 cited in Sonderling and Bothma, 2005:36). She also called for people to give feedback so that the 'people first' gateway could be made more 
user-friendly (SouthAfrica.info, 2004). Speaking at the launch of the community development workers' programme in Winterveldt in the Western Cape in 2005, the Minister urged workers to "... live with the people, walk with them and talk their language".

Mobile e-government is also being embraced as an option, that is, the delivery of e-government via mobile services or m-government (Rossel, Finger and Misuraca, 2006: 83). Recognising that only 20\% of South Africa's some 30000 schools had at least only one computer, the Digital Doorway project, aimed at wide-scale computer literacy, established some 150 kiosks in remote rural and peri-urban areas between 2002 and 2007, at a cost of ZAR48 million. These robust kiosks use keyboard and touchpad technology and are backed by a joint project of the Department of Science and Technology, the CSIR and Eskom (Opening SA's digital doorway, 2007).

The statistics in this section provide information about the current state of access to telephony. Mostert (2005:61) sees the telecommunications system in South Africa as well-developed. By March 2002 the country had 4.96 million telephone lines (Jensen, 2002). Substantial developments with fixed-line prepaid lines, payphones and Integrated Services Digital Network channels are reported by Burger (2002), but IndexMundi (2007) gives a figure of 4,729,000 main lines in use in April 2007, while Research ICT Africa (2008) reports that fixed line growth is almost static, despite the option of pre-payment for services. Only 18 percent of households in their survey reported having a working fixed line facility. Mobile phone sales totaled 15 million in 2003 and were expected to grow to 21 million in 2006 (Burger 2004). IndexMundi (2007) reports the figure of 33,960,000 mobile phones in April 2007. Three service providers offer mobile phone coverage.

There are some very positive examples where cell phone technology is assisting with information access in agriculture, banking and health. In agriculture, small-scale sugarcane farmers are using this technology to receive information on when to irrigate their crops. They are part of a pilot project of the South African Sugar Association at Pongola in Mpumalanga and Makhathini in KwaZulu-Natal. Farmer Themba Mthembu states: "We receive these SMSs in our mother language, making it easy for us to use." Another farmer, Thandi Simelani, reports that the scheme has helped improve her cane output (SMS alerts boost sugarcane output, 2008).

Another example from the banking sector targets the 48 percent of adult South Africans who do not have bank accounts. The mobile banking provider WIZZIT enables thousands of people to make retail purchases without cash, transfer funds, buy airtime and pay bills. These accounts cost about a third of the usual price for such services and the subscription is activated by punching information into a telephone keypad (Upwardly mobile, 2008).

In the area of health education and information, the Indian company ZMQ Software Systems has designed mobile phone games to educate the public in the local language about HIV/AIDS. The project is expanding to Africa, including South Africa (Upwardly mobile, 2008).

While such examples of ready and appropriate forms of ICT access hold promise for addressing access, equity and development issues in the future, Research ICT Africa (2008) reports that the high costs of data services which are capable of Internet functionality such as GPRS and 3G reduce their potential for use. Apart from the high costs of handsets in the South (Upwardly mobile, 2008), many mobile receivers are not enabled for enhanced services. The Research ICT Africa survey (2008) revealed that only in Mozambique and Kenya, where prices are lower, were mobile phones used to access the web to a significant extent. The high cost of calls means that many people remain reliant on public access phones.

\section{Education and training}

Education for library and information work in South Africa commenced in 1933 and its development is described elsewhere (Stilwell, 2007a). Today, eleven institutions offer LIS education and training. This sector has experienced considerable change since 1994 in response to policy frameworks (Raju, 2004:4-7) such as the National Commission for Higher Education's (NCHE) Policy Framework for Higher Education Transformation (1996) and the subsequent white paper (Department of Education, 1997a), the New Academic Policy for Programmes and Qualifications in Higher Education: Discussion Document (Council on Higher Education, 200I), and the Approved Academic Programmes for Universities and Technikons: 2003-2006 (Ministry of Education, 2002).

The offerings in the handbooks and web pages of the local institutions show the varied response of programmes to shifts in demand. The nomenclature of the programmes varies considerably, with two devoted mainly to Knowledge and Information Management. UCT has a Centre for Information Literacy. While offering Information Literacy as a compulsory core module (Bothma, 2006), UP leans more heavily towards information science and multimedia. UKZN has a strong information literacy offering as well as a substantial school library programme.

There is a range of offerings and qualifications, with 3 and 4 year degrees, 3 year diplomas in the universities of technology and postgraduate diplomas following on a bachelor's degree. Most university based programmes offer 
honours, masters and doctoral programmes. The universities of technology offer a Bachelor of Technology degree (Ocholla and Bothma, 2007). The distinctions between their offerings and those of the universities are addressed by Raju (2004).

Some institutions, such as the University of Johannesburg (UJ) and UNISA, operate largely or exclusively by distance education, whereas others such as UKZN use a mixed mode of distance and on site delivery, for example, in delivering the ACE. The University of the Western Cape (UWC) offers an ACE via a series of short courses.

Articulation between institutions and their offerings, especially for those wishing to move from the paraprofessional training of the universities of technology to professional education and training in the universities, has been addressed by the Research, Education and Training Group (RETIG) of the Library and Information Association of South Africa (LIASA). RETIG has played a crucial role in guiding these deliberations and in ensuring coherence across programmes (Ocholla, 2007). Offerings are also under discussion by the Standards Generating Body for Information and Library Services appointed by the South African Qualifications Authority within the National Qualifications Framework (Walker, 2005:35). Ocholla and Bothma (2007:12) usefully describe the common core offerings of local LIS schools: information and knowledge management, information storage/seeking and retrieval, knowledge organisation, knowledge representation and ICTs. These authors also point to the need to respond to needs for change in curricula and to the crucial role in quality assurance played by heads of department, external examiners, and regular external evaluations.

\section{The organised profession}

LIASA hosted the 2007 World Library and Information Congress in Durban, has been recognised by IFLA as a new member of the international association and is a member of the Standing Conference of East, Central and Southern African Librarians (SCECSAL) and of the Commonwealth Library Association (COMLA) (Walker, 2005).

Walker (2005) describes the development of the library and information associations in South Africa, commencing in 1930. Since July 1997, library and information workers have been represented primarily by LIASA, which had 2,207 paid up members in 2002 (Ledwaba, 2002:3). LIASA enjoyed financial support from the Carnegie Corporation for a 3-year period from 2000 to develop an administrative structure for the association (Rosenberg, 2006: I I I).

LIASA has established ten branches in nine provinces and has strong interest groups in the following areas: Public Libraries, Bibliographic Information, Acquisitions, Inter Library Loans, Higher Education Libraries and Research, Education and Training. LIASA also publishes a magazine and a newsletter, both quarterly (Walker, 2005:33-34).

The association has had a successful Library Leadership Project, funded by the Mellon Foundation, which was followed by a Carnegie Corporation-funded second phase. This is headed by a Centre for Information Career Development $(\mathrm{CICD})$ which seeks to provide sustainable continuing professional education and training (Walker, 2005:35).

The many questions that relate to the capacity of this body are addressed by Underwood (2003) and Walker (2005). LIASA is a "professional" body that includes in its membership those without professional qualifications and status. There is also discussion about LIASA playing the dual role of professional body and trade union (Raju, 2006). Stilwell (2007b) comments: "LIASA's inclusiveness is ironically both its weakness and its strength. Its future will depend in large measure on its ability to fast track the education and training of its membership. In this regard the role of the CICD will be a critical one."

Other significant specialised groups which work closely together are the Special Libraries and Information Services Group (SLIS: n.d.), the South African Online User Group (SAOUG: 2008) and the Organisation of South African Law Schools (OSALL: n.d.).

\section{Conclusion}

This article follows on Part I which provided an overview of information policy and information sources, systems and some services in South Africa (Stilwell, 2008). It picked up on libraries and information services in South Africa as part of the wider national information system, starting with the critical issues of school libraries. An overview of archives, record centres and museums, non-governmental organisations (NGOs), embassies, the commercial database industry and indigenous knowledge came next. The sectors concerned with the dissemination of information and information technology were described. A description of the library and information education and training sector and the organised profession followed.

Some of the future challenges for the sector have been addressed more fully in Stilwell (2007b). In terms of the fit between the national transformation agenda and its relationship to the achievements of this sector, it is clear that although a great deal has been accomplished, many developments which are still in progress need to be carefully evaluated. Useful 
examples and a wealth of first hand experience are available to inform future projects. Much still remains to be done, particularly with reference to some of the sectors mapped in this article.

\section{References}

Aitchison, J.M.H. 2006. Experiments in the provision of rural community information in South Africa. Innovation, 32:94-109.

Behrens, S.J. 2000. Bibliographic control and information sources. $3^{\text {rd }}$ ed. Pretoria: UNISA Press.

Boekhorst, A. and Britz, J. 2004. Information literacy at school level: a comparative study between the Netherlands and South Africa. South African Journal of Libraries and Information Science, 70(2):63-7I.

Boon, J.A. 1992. Information and development: towards and understanding of the relationship. South African Journal for Library and Information Science, 60(2):63-72.

Burger, D. (ed.) 2002. South Africa yearbook 2002/3. $6^{\text {th }}$ ed. Pretoria: GCIS.

Burger, D. (ed.) 2004. South Africa yearbook 2003/4. $7^{\text {th }}$ ed. Pretoria: GCIS.

Chisholm, L. 2005. The state of South Africa's schools. In: Daniel, J., Southall, R. and Lutchman, J. (eds). State of the nation: South Africa 2004-2005. Cape Town: Human Sciences Research Council Press, pp 210-226.

Committee of University Principals (CUP). 1990. Review of librarianship: final report. n.p.: CUP.

Communications in South Africa. 2008. Wikipedia. Available at http://en.wikipedia.org/wiki/Communications_in_South_Africa (Accessed 22 April 2008).check both Partl and II.

Constitution of the Republic of South Africa. 1996. Act 108 of 1996. Pretoria: Government Printer.

Contact directory. 2006. Available at http://www.gcis.gov.za/docs/directories/index.html (Accessed 27 March 2007).

Council on Higher Education. 200I. New academic policy for programmes and qualifications in higher education: discussion document. [Pretoria]: Department of Education.

Darch, C., Rapp, J. and Underwood, P.G. 1999. Academic library consortia in contemporary South Africa. Library Consortium Management: an International Journal, I(I/2):23-32.

De Vries, L.C. and Van der Merwe, R. 2004. School libraries in the Northern Cape Province - where do we stand? South African Journal of Libraries and Information Science, 70(2): 121-131.

Du Toit, M. 2008. The KwaZulu-Natal School Library Policy and its feasibility for implementation in the Province. PhD thesis under examination (Information Studies). Pietermaritzburg: University of KwaZulu-Natal.

Department of Education. 1997. School register of needs survey. Pretoria: Department of Education.

Department of Education. 1998. National norms and standards for the funding of schools. Pretoria: Department of Education.

Department of Education. 2004. White paper on e-Education: transforming teaching and learning through information and communication technologies. Pretoria: Department of Education.

Department of Education. 2005. Draft national school library policy. Pretoria: Department of Education.

Department of Education. 2007. Minister of Education, Naledi Pandor, goes on a Rally to Read in the North West Province. Press release, 10 May. Available at $h t t p: / / w w w . e d u c a t i o n . g o v . z a / d y n a m i c / d y n a m i c . a s p x ?$ pageid=310\&id=2997. (Accessed 22 April 2008).

Department of Education and Human Sciences Research Council. 1999. South African school library survey: final draft. Pretoria: Department of Education/HSRC.

Dick, A. 2006. Innovation: looking back, looking forward. Address at the launch of the new format of Innovation, 19 October, University of KwaZulu-Natal, Pietermaritzburg. Available at http://www.library.unp.ac.za/InnovationLaunch.htm (Accessed 18 January 2006).

Ebsco Information Services. 2007. Available at http://www.ebsco.com/home/ (Accessed 27 March 2007).

Emdon, C. 2002. E-governance can advance aims of Nepad. Business Day, 8 November. Cited in Sonderling and Bothma, 2005.

Emerald Insight [n.d.]. Available at http://www.emeraldinsight.com/Insight/menuNavigation.do?hdAction=InsightHome (Accessed 27 March 2007).

Europa world yearbook. 200I. $42^{\text {nd }}$ ed. Vol II. London: Europa.

Government Communication and Information System (GCIS). 2007. Available at http://www.gcis.gov.za (Accessed 27 March 2007).

Government mag to reach rural areas. 2005. Available at www.southafrica.info/ess_info/sa_glance/media/vukuzensele-300905.htm (Accessed 8 April 2008).

Gxwati, Z. 2007. WLIC conference 2007 - report. LIASA School Library Youth and Information Services Interest Group Newsletter, December.

Harris, V. 2002. Contesting remembering and forgetting: the archives of South Africa's Truth and Reconciliation Commission. Innovation, 24:I-8.

Hart, G.C. 2006a. Public librarians and information literacy education: views from Mpumalanga Province. South African Journal of Library and Information Science 72(3): 172-184.

Hart, G.C. 2006b. Educators and public librarians: unwitting partners in the information literacy education of South African youth. Innovation, 32:74-93.

Hoskins, R. 2006. Libraries and teacher-librarians in KwaZulu-Natal. Innovation, 33:59- 75.

Independent Online (2007). Available at $h t t p: / / w w w . i o l . c o . z a /$ (Accessed 27 March 2007).

IndexMundi. 2007. Available at http://www.indexmundi.com/south_africa (Accessed 22 April 2008).

Internetworldstats.com.2007a. World Internet usage and population statistics. Available at http://www.internetworldstats.com/ stats.htm (Accessed 23 March 2007).

Internetworldstats.com. 2007b. Internet usage statistics for Africa. Available at http://www.internetworldstats.com/ stats I.htm\#africa_(Accessed 23 March 2007). 
Jensen, M. 2002. The African Internet: a status report. Available at http://www3.wn.apc.org/africa/afstat.html (Accessed 22 January 2006).

Kaiser, A. 2006. E-mail letter, as Resource Centre Manager, Khanya College, Johannesburg to the author. 25 October.

Kaniki, A.M. and Mphahlele, M.E.K. 2002. Indigenous knowledge for the benefit of all: can knowledge management principles be used effectively? South African Journal of Libraries and Information Science, 68(I):I-I5.

Karlsson, J. 2005. The transformation of teaching and learning in the e-education age. Keynote address to the e-Education and ELITS Conference, March 2I-23, Bloemfontein.

KwaZulu-Natal. Department of Education. 2003. School library policy. Durban: Department of Education.

KwaZulu-Natal. Department of Education. 2004. Analysis of the 2004 ELITS school library audit. Unpublished report. Directorate: Education Library Information and Technology Services. Durban: EduAction.

Le Roux, S. and Hendrikz, F. 2006. Joint use libraries: implementing a pilot community/school library project in a remote rural area in South Africa. Library Trends, 54(4):6। 8-637.

Leach, A. 2007. Personal communication as lecturer responsible for the UKZN Post Graduate Diploma in Information Studies, Information Sciences and Agencies module, Pietermaritzburg, 9 January.

Ledwaba, H. 2002. Library and information services sector in South Africa: challenges and issues facing the profession. Paper to the American Library Association Conference, 16 June, Atlanta, Georgia.

Library Practice for Young Learners (LPYL). 2002. A Swedish-South African School library project: 1997-2002. Available at http://www.foreningenbis.org//pyl/exhibiton-text I.htm (Accessed I9 March 2008).

Libraries for South African schools. 2008. South Africa Partners, Inc. Available at http:/www.sapartners.org/programs/ libraries.php3 (Accessed 4 April 2008).

Lundall, P. and Howard, C. 2000. Computers in schools: a national survey of information and communication technology in South African schools. Belville: Education Policy Unit, University of Western Cape. Cited in Zinn, 2006.

Mail and Guardian Online. 2007. Available at http://www.mg.co.za/ (Accessed 27 March 2007).

Merrett, C.E. 2005. The Hefer Commission: its significance for the South African national information system. Innovation, 30:12-20.

Ministry of Education. 2002. Approved academic programmes for universities and technikons: 2003-2006. Pretoria: Department of Education.

Mostert, J.B. 2005. Parliamentary information sources, systems and services in South Africa. South African Journal of Libraries and Information Science, $7 \mathrm{I}(\mathrm{I}): 5 \mathrm{I}-63$.

Musiker, R. 1986. Companion to South African libraries. Cape Town: Donker.

National Archives Act. 1996. Act 43 of 1996. Pretoria: Government Printer.

National Commission for Higher Education's (NCHE). 1996. Policy framework for higher education transformation. Available at http://star.hsrc.ac.za/nche/final/transform/l.htm (Accessed 25 July 1999).

National Inquiry Services Centre South Africa [n.d.] Available at http://www.nisc.co.za/ (Accessed 27 March 2007).

News24. 2006. Available at http://www.news24.com/News24/South_Africa/Politics/0,2-7-12_2012490,00.html (Accessed 27 March 2007).

News24. 2007. Available at http://www.news24.com/News24/Home/ (Accessed 27 March 2007).

Ngulube, P. 2003. Preservation and access to public records and archives in South Africa. PhD dissertation. Pietermaritzburg: University of KwaZulu-Natal.

Nzimande, E.S. and C.Stilwell. 2008. Sharing information resources: a study of school clusters from rural KwaZulu-Natal, South Africa. Libri, forthcoming.

Ocholla, D.N. 2006. Information accessibility by the marginalized communities in South Africa and the role of libraries. In IFLA/ FAIFE Theme Report 2006: Libraries and the fight against HIV/AIDS, poverty and corruption, pp.I5-27. Available at $h t t p: / /$ www.ifla.org/faife/report/WorldReport-pr-2006.htm (Accessed 10 July 2008).

Ocholla, D.N. 2007. The current status and challenges of collaboration in Library and Information Science (LIS) education and training in Africa. Paper presented at the $73^{\text {rd }}$ IFLA General Conference, 19-23 August, Durban. Available at: http:// www.ifla.org//V/ifla73/papers/I34-Ocholla-en.pdf (Accessed I0 July 2008).

Ocholla, D.N. and Bothma, T. 2007. Trends, challenges and opportunities of LIS education and training in Eastern and Southern

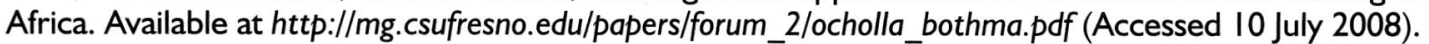

Organisation of South African Law Schools. [n.d.]. About OSALL. Available at sunsite.wits.ac.za/osall (Accessed 7 July 2008).

Opening SA's digital doorway. 2007. Available at http://www.southafrica.info/about/education/digitaldoorway.htm (Accessed 21 April 2008).

Peters, D. 200 I. The Campbell Collections digitization project. E-mail message to A.M. Kaniki, I3 November. Cited in Kaniki and Mphahlele, 2002.

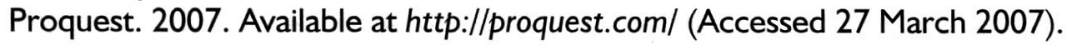

Raju, J. 2004. The historical evolution of university and technikon education and training in South Africa: implications for articulation of LIS programmes. Innovation, 29:1-12.

Raju, J. 2005. LIS education and training in South Africa: a historical review. South African Journal of Libraries and Information Science, 7 I (I):74-84.

Raju, R. 2006. Investigation into the acquisition of statutory status for the South African LIS sector. South African Journal of Libraries and Information Science, 72 (2): 131 - 140.

Research ICT Africa. 2008. ICT access and usage in South Africa. South Africa Policy Brief, No I. Available at http:// www.researchICTafrica.net (Accessed 25 June 2008).

Rosario, J. and Molapo, L. 2005. The Shongololo Interconnectivity Pilot Project: a work in progress. International Journal of Education and Development using Information and Communication Technology I(2): I56-162.

SA Jnl Libs \& Info Sci 2009, 75(I) 
Rosenberg, D. 2006. Review of A. Olden and Mcharazo, A. (eds). Revitalizing library associations in Africa, Innovation, 3 I. Focus 37(3): II0-III.

Rossel, P., Finger, M. and Misuraca, G. 2006. "Mobile” e-Government options: between technology-driven and user-centric. Electronic journal of e-Government 4(2): 79-86. Available at http://www.ejeg.com/volume-4/vol4-iss2/Rossel_et_al.pdf (Accessed 29 May 2008).

SABINET Online. 2007. Available at http://www.sabinet.co.za/ (Accessed 27 March 2007).

SMS alerts boost sugarcane output. 2008. Spore 134 (April). Available at http://spore.cta.int/index.php?option=com_content\&task=view\&id=4I3\&catid=12 (Accessed 24 June 2008).

Scholtemeyer, P. 2002. Magazines in South Africa. Available at http://www.fipp.com/Default.aspx?Pagelndex $=2002 \& / t e m / d=42$ (Accessed 21 April 2008).

Sonderling, N.E. and Bothma, T.J.D. 2005. Developing the SAPs website for optimal service delivery. South African Journal of Libraries and Information Science, 7 I (I):26-37.

South African Broadcasting Corporation. 2006. Wikipedia. Available at http://en.wikipedia.org/wiki/SABC (Accessed 2I April 2008)

South African newspapers. 2008. Available at http://www.onlinenewspapers.com/sa.htm (Accessed 25 June 2008).

South African Police Services. [n.d.]. Available at http://www.saps.gov.za/ (Accessed 28 March 2007).

South African Studies [n.d.]. Available at http://www.nisc.co.za/databases?id=7 (Accessed 27 March 2007).

South African yearbook. 2005/2006. Available at http://www.gcis.gov.za/docs/publications/yearbook06.htm (Accessed 27 March 2007).

South African yearbook. 2006/07. Available at http://www.gcis.gov.za/docs/publications/yearbook/2007/chapterl.pdf (Accessed 29 May 2008).

SouthAfrica.info. 2004. SA govt's 'people first' portal. Available at http://www.southafrica.info/services/government/ sagovtonline.htm (Accessed 8 April 2008).

SouthAfrica.info. 2005. South Africa's community workers. Available at http://www.southafrica.info/services/government/ communityworkers.htm (Accessed 29 May 2008).

SouthAfrica.info. 2008a. South Africa's telecommunications. Available at http://www.southafrica.info/ business/economy/ infrastructure/telecoms.htm (Accessed 21 April 2008).

SouthAfrica.info. 2008b. Press freedom in South Africa. Available at http://www.southafrica.info/about/media/press-freedom.htm (Accessed I July 2008).

Southern African Online User Group. 2008. About SAOUG. Available at http://www.saoug.org.za/about.htm (Accessed 24 April 2008).

Special Libraries and Information Services Group. n.d. Aims and objectives. Available at http://www.slis.co.za/home.asp?pid=/5 (Accessed 24 April 2008).

Stilwell, C. 200I. Community resource centres: a turn of the century update. In: Stilwell, C., Leach, A. and Burton, S. (eds). Knowledge, information and development: an African perspective. Pietermaritzburg: School of Human and Social Studies, University of Natal, pp. 200-2I4.

Stilwell, C. 2007a. Library and Information Services in South Africa: an overview. IFLA Journal, 33(2): 87-108.

Stilwell, C. 2007b. South African LIS futures and the tale of the fisherman's wife: can we predict and create positive change? In Bothma, T., Underwood, P. and P. Ngulube. eds. Libraries for the future: progress and development of South African libraries. Pretoria: LIASA Department of Arts and Culture, pp. 199-218.

Stilwell, C. 2008. Mapping the fit: library and information services and the national transformation agenda in South Africa, Part I. South African Journal of Libraries and Information Science, 74(2): 149-160.

Underwood, P. 2003. Recognition of prior learning and the development of the library and information profession in South Africa. South African Journal of Libraries and Information Science, 69(I):49-54.

Upwardly mobile. 2008. Spore 134 (April). Available at http://spore.cta.int/ index.php?option=com_content\&task=view\&id=4I3\&catid = I 2 (Accessed 24 June 2008).

Verbeek, C. 2008. Getting children reading. The Witness, 4 June. Available at http://www.witness.co.zal ?showcontent\&global[_id] =8505 (Accessed 3 July 2008).

Waka-Zamisa, S. and Shoba, N. 2007. No fees at half KZN's schools. Witness, 17 January: I.

Walker, C.M. 2005. Library associations in South Africa, 1930-2005. Library Management, 27(1/2):26-37.

Western Cape Education Department. 2005. Grade 6 systemic evaluation: Western Cape Province. Cape Town: Western Cape Department of Education.

Western Cape Education Department. 2006. A human capital development strategy for the Western Cape: a focus on youth. Cape Town: Western Cape Department of Education.

Wilson-Strydom, M., Thomson, J. and Hodgkinson-Williams, C. 2005.Understanding ICT integration in South African classrooms. Perspectives in Education, 23(4):71-85.

Zinn, S. 2006. Have trained school librarians made a difference for school libraries in South Africa? Innovation, 33:2I-35. 